Zagazig J. Agric. Res., Vol. 43 No. (3) 2016

http:/www.journals.zu.edu.eg/journalDisplay.aspx?Journalld=1\&queryType=Master

\title{
ENGINEERING STUDIES ON FLAX FIBER EXTRACTION
}

\author{
Mohamed I.A. Fayed $^{{ }^{*}}$, M.S. El-Shal ${ }^{1}$, A.S. El-Ashry ${ }^{2}$ and Hanan M. El-Shal ${ }^{1}$ \\ 1. Agric. Eng. Dept., Fac. Agric., Zagazig Univ., Egypt \\ 2. Agric. Eng. Inst., Agric. Res. Cent., Dokki, Egypt
}

\begin{abstract}
Nowadays, there is an intention to increase the flax fiber exportation as well as local industry which depend to a great extent on the fiber quality. The degree of retting is the single most important factor govering the mechanical extracting of the fiber from the stem. So, it is very important to improve retting methods for the flax straw. In Egypt, two mechanized systems for extracting flax fiber from the stem (partial mechanized system and complete mechanized system). The main aim of this research was to optimize the necessary recommendations which are needed to best flax fiber extraction with a low cost, energy and high efficiency. The results showed that the proper system to execute the extracting operation of flax fiber under local condition is the complete mechanized system, which give the highest values of flax fibers separation percentage of $(96.30 \%)$, flax fiber length of $(101.00 \mathrm{~cm}$.), long fiber percentage of $(23.42 \%)$, Fiber fineness of $(285.45 \mathrm{~mm} / \mathrm{mg}$.), long fiber strength of $(28.42$ $\mathrm{mm} . \mathrm{N} / \mathrm{mg}$.), the lowest values of specific energy for separating one Mg of flax straw of (40.06 kW.hr $/ \mathrm{Mg})$ and criterion costs of $(504.59 \mathrm{LE} / \mathrm{Mg})$.
\end{abstract}

Key words: flax fiber, retting, partial, complete, scutching, fiber extracting.

\section{INTRODUCTION}

Flax (Linum usitatissimum L.) is considered one of the most important economical crops due to, it is a source of heavy (idle) oil and special fibers used in different scopes of industry. The cultivated areas in Egypt reach up to 23810 Faddans (FAO statistical, 2013).

After harvesting flax crop, the flax plants were left in the field for 3 to 4 days in small piles for natural drying and later gathered into large heaps in the threshing yard. Flax crop was sun dried for a few hours to extract the moisture that the plants were picked up during the night since the crop was not stored in an enclosed building. Sheets are stretched out to perform the deseeding operation on it by threshing and cleaned by winnowing unit. After threshing process, flax straw are compiled in bundles and stored until it is retting. The usable flax fibers are extracted from the bast tissue of the flax stem. The scutched flax is ready to be combed

* Corresponding author. Tel. : +201013432036

Email address: dr_eng.fayed@yahoo.com (heckled) and processed further into yarn and eventually into linen textiles.

Azza et al. (2012) showed that the flax fiber was bound to outside of the woody stem then it was impregnated in water at open or closed rooms. The flax was retted with mesophilic temperature $37^{\circ} \mathrm{C}$ for $7-10$ days till $\mathrm{pH}$ reaches 4.5 where fibers were separated from the woody materials by natural degradation. The retting wastewater was discharged without any treatment to main agricultural drain.

Konczewicz et al. (2013) found that warm water retting is performed at a temperature around $35^{\circ} \mathrm{C}$, and this can shorten the retting period to 100 hours, due to the high water consumption and unpleasant stench generated.

Tahir et al. (2011) showed that chemical and enzymatic retting methods are used as well, and these offer more control than dew and water retting. However, chemical retting, an aggressive degumming method, incurs significant pollution problems due to the large 
quantity of chemicals utilized, while enzymatic retting is quite expensive, even though by requiring a shorter retting time and obtaining acceptable fiber quality it carries apparent advantages over the other retting processes.

Nair et al. (2011) showed that the flax stems after retting process always contain high amount of water. The drying of retted stem is conducted by hot air drying.

Bos (2004) showed that after the fibers have been loosened from the stem, the stem is broken on a brake by leading it between fluted rollers. The broken stem parts are then removed from the fiber bundles in the scutching turbine, which basically scrapes the fibers, thereby removing the broken woody stem parts, the shives. The scutching turbine exists of two interpenetrating rollers equipped with three or more knives. The knives scrape along the fiber, but since the knives are relatively sharp, they also bend the fibers just below the point of contact, introducing microstructural defects in the form of kink bands over the entire fiber length. The total process to remove the wooden stem from the fibers is also called decortication.

Singh and Bargalo (2000) measured directly by torque and rotating speed, the accurate screw torque meter for bench scale equipment is expensive. If measured indirectly through the electrical energy input, the efficiency of motor should be taken into account, but motor efficiency data are often not available.

The objectives of this work are:

1. Study the effect of some parameters on extracting degree of flax fibers.

2. Evaluate some technological properties of flax fibers in relation to different retting methods.

3. Improve the water retting in cement basin methods (Traditional retting methods).

4. Select the proper system for extracting flax fibers with a low cost, low energy and high efficiency.

\section{MATERIALS AND METHODS}

The experiments were carried out from 2013 to 2015 at Shobrameles Village, El-Gharbia Governorate, Egypt, to evaluate flax fiber extraction systems under different retting methods and scutching equipment.

\section{The Used Crop}

To evaluate two flax fiber extract systems under study, one variety of flax crop (Belinka) was used. Estimating the technical length is essential to determine the upper length of plants that entered to the breaking machine chamber in order to obtain high extracting efficiency with minimum fiber losses. Technical length of plants is (the mean length of stems) starting from the connection point of root with stem to the first productive branch (as shown in Table 1).

\section{Scutching Systems}

The retted dried straw was broken by special rolling machine, then scotched for extracting the flax fiber. Two scutching systems were investigated as follows:

1. Partial mechanized system.

2. Complete mechanized system.

\section{Partial mechanized system}

This system involved of breaking machine, scutching mill, and tractor as shown in Fig. 1.

\section{Breaking machine}

The main specifications of this machine are: total height of $(152 \mathrm{~cm})$, width of $(100 \mathrm{~cm})$, length of $(196 \mathrm{~cm})$ and total mass of $(535 \mathrm{~kg})$. It consists mainly of six pairs of rollers, each lower roll is held against the upper roll by spring pressure which can be regulated. Each roller was fabricated from hard steel at length of (70 $\mathrm{cm})$, diameter of $(12.1 \mathrm{~cm})$ and mass of $(14 \mathrm{~kg})$. 12 springs (10 cm free length) at the corners of the upper rollers provided the force compression of $\left(318 \mathrm{~N} / \mathrm{m}^{2}\right)$ required by adjust the gap clearance between two rollers. The retted straw is fed at first pair rollers and is discharged from the rear enzd of the machine (as shown in Fig. 2).

\section{Scutching mill}

The scutching machine removes the tow as well as shive from the fibers, at speed of 1075 rpm, while the fiber is held by the hand (as shown in Fig. 3).

\section{Power source}

A Nasr DM 34 tractor $62 \mathrm{hp}(46.26 \mathrm{~kW})$ diesel engine was used as power source. 
Table 1. Physical properties of flax crop Belinka variety

\begin{tabular}{lc}
\hline Physical characteristics & Mean value \\
\hline Plant height,(cm) & 110 \\
Technical length, (cm) & 100 \\
Stem diameter, (mm) & 1.9 \\
Straw yield and capsule, (Mg/fad.) & 3.75 \\
Straw yield, (Mg/fad.) after retting & 2.25 \\
Fiber percentage & $25 \%$ \\
Fiber length, (cm) & 77.5 \\
Fiber fineness, (mm /mg) & 230 \\
\hline
\end{tabular}

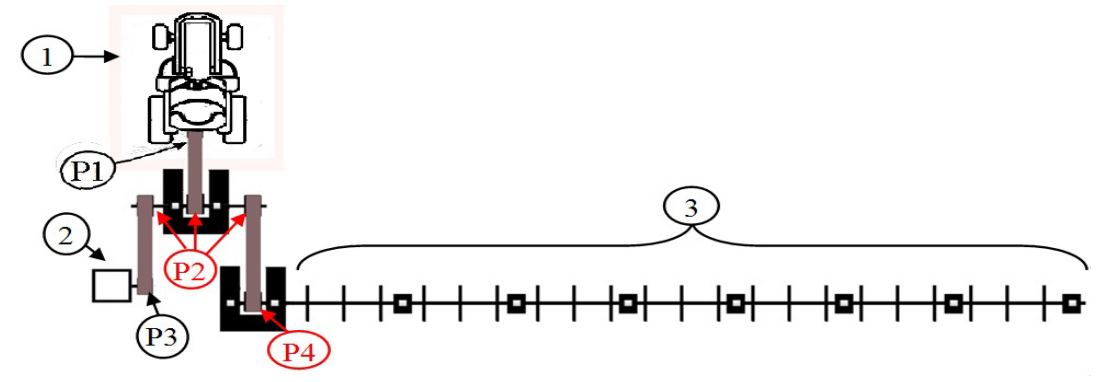

\begin{tabular}{clcl}
\hline No. & Part name & No. & Part name \\
\hline 1 & Tractor & P1 & P.T.O. Pulley \\
2 & Breaking machine & P2 & Three main pulley \\
3 & Scutching mill & P3 & Pulley breaking machine \\
& & P4 & Pulley scutching mill \\
\hline
\end{tabular}

Fig. 1. Schematic diagram of partial mechanized system

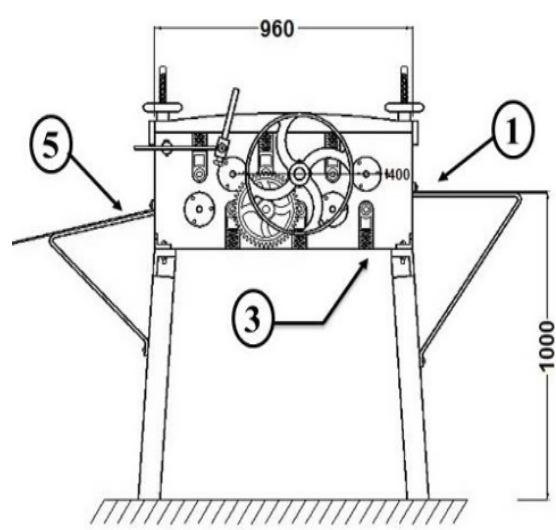

Elevation

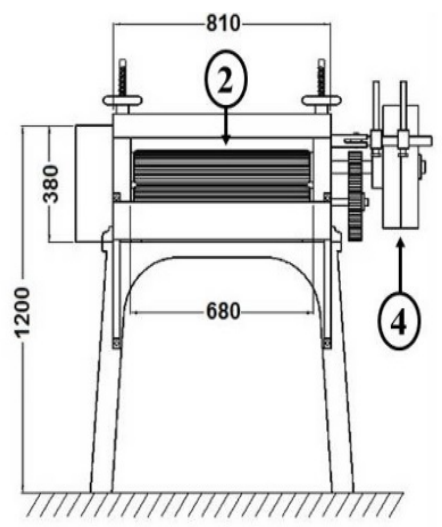

Side view

Dimensions in $\mathbf{m m}$.

\begin{tabular}{llll}
\hline No. & Part name & No. & Part name \\
\hline 1 & Feeding get & 4 & Working pulley \\
2 & Breaking drum & 5 & Get let out \\
3 & Spring pressure & & \\
\hline
\end{tabular}

Fig. 2. Schematic diagram of breaking machine 


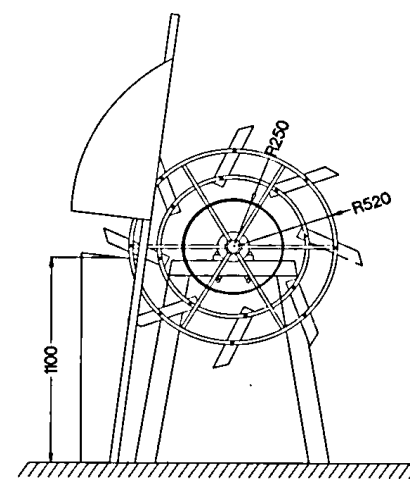

Dimensions in $\mathbf{m m}$.

Fig. 3. Schematic diagram of scutching mill

\section{Complete mechanized system}

This system conducted mechanical extracting using Turbine machine (as shown in Fig. 4).

\section{Feeding shelf}

Scutching turbine begin table to dismantle the flax straw bundles, and to provide for a uniform transit of the stems, with then the divider (group of gears) thins the thickness of the bunch of stems by means of a uniform rising speed, and regulate the entry of stems into breaking.

\section{Breaking unit}

It consists mainly of ten pairs of rollers, at speed of $970 \mathrm{rpm}$., each lower roll is held against the upper roll by spring pressure which can be regulated.

\section{Scutching mill}

It consists of two units for processing dusting and removing shive (hurds or elsas) from fibers, at speed of $1290 \mathrm{rpm}$.

\section{Reception fiber knife}

The end of the line the turbine provide knife to reception of fibers and the belts guarante a good sight while sorting.

\section{Retting Basin}

The straw of deseeded flax plants was arranged in a bundle and put in cement basins. Since the size of retting basins $12 \times 12 \times 1.5 \mathrm{~m}$. It is shown in Fig. 5. The mean temperature of the water was 28-30 and the $\mathrm{pH}$ value was 6-7, while the ratio between straw and water was 1: 13 .
The retted straw was washed with clean water and dried in open air.

\section{Experimental procedure}

The Factors involved in this study were:

1. Two mechanized systems for extracting flax fiber

a) Partial mechanized system (mechanical breaking and scutching mill).

b) Complete mechanized system (mechanical extracting using scutching turbine).

2. Three methods of water retting

a) Retting in still water (without changing water).

b) Retting with changing the water in basin every 48 hours.

c) Retting with changing the water in basin every 24 hours (daily).

3. Four levels of straw moisture content of 8.76, $10.15,11.90$, and $14.35 \%$ wet basis (w.b.).

Straw moisture content of flax was determined using oven drying method according to ASAE standard, 1992 after retting at three different drying stages by taking five straw samples randomly (after 10, 12, 15 and 20 days from retting, and drying them in the oven at $70^{\circ} \mathrm{C}$ for 24 hours). The straw moisture content was calculated as follows:

$$
\mathrm{M}=\frac{\mathrm{W}_{\mathrm{ws}}-\mathrm{W}_{\mathrm{ds}}}{\mathrm{W}_{\mathrm{ws}}} \times 100
$$


Where:

$\mathrm{M}=$ Straw moisture content (\%), $\mathrm{W}_{\mathrm{ws}}=$ Wet straw mass, $(\mathrm{g}), \mathrm{W}_{\mathrm{ds}}=$ Dry straw mass, $(\mathrm{g})$.

\section{Experimental measurements}

\section{Flax fibers separation percentage}

The extracting percentage was estimated by using the following equation:

Where:

$$
\mathrm{F}(\%)=\frac{\mathrm{W}_{\mathrm{f}}}{\mathrm{W}_{\text {straw }}} \times 100
$$

$F(\%)=$ Flax fibers separation percentage, $(\%)$, $\mathrm{W}_{\mathrm{F}}=$ Total mass of fiber, $(\mathrm{kg})$, and $\mathrm{W}_{\text {straw }}=$ straw yield after retting (straw into system), $(\mathrm{kg})$.

\section{Technological properties of flax fibers}

\section{Fiber length}

A random sample of fiber from each treatment was spreaded out and each ribbon was measured by using a scale meter $(\mathrm{cm})$, then the mean fiber length was recorded. Knowing that flax long fiber $>600 \mathrm{~mm}$, and flax short fiber $<600 \mathrm{~mm}$.

\section{Long fiber percentage}

Long fiber percentage was estimated according to Radwan and Momtaz (1966), using the following equation:

$$
\mathrm{L}_{\mathrm{f}}=\frac{\mathrm{W}_{\mathrm{f}}-\mathrm{S}_{\mathrm{f}}}{\mathrm{W}_{\mathrm{f}}} \times 100
$$

Where:

$\mathrm{L}_{\mathrm{f}}=$ long fiber percentage, $(\%) \cdot \mathrm{W}_{\mathrm{f}}=$ Total mass of fibers, and $S_{f}=$ mass of short fibers.

\section{Fiber fineness}

Fiber fineness in metrical number $(\mathrm{mm} / \mathrm{mg})$, was determined according to Radwan and Momtaz (1966) using the following formula:

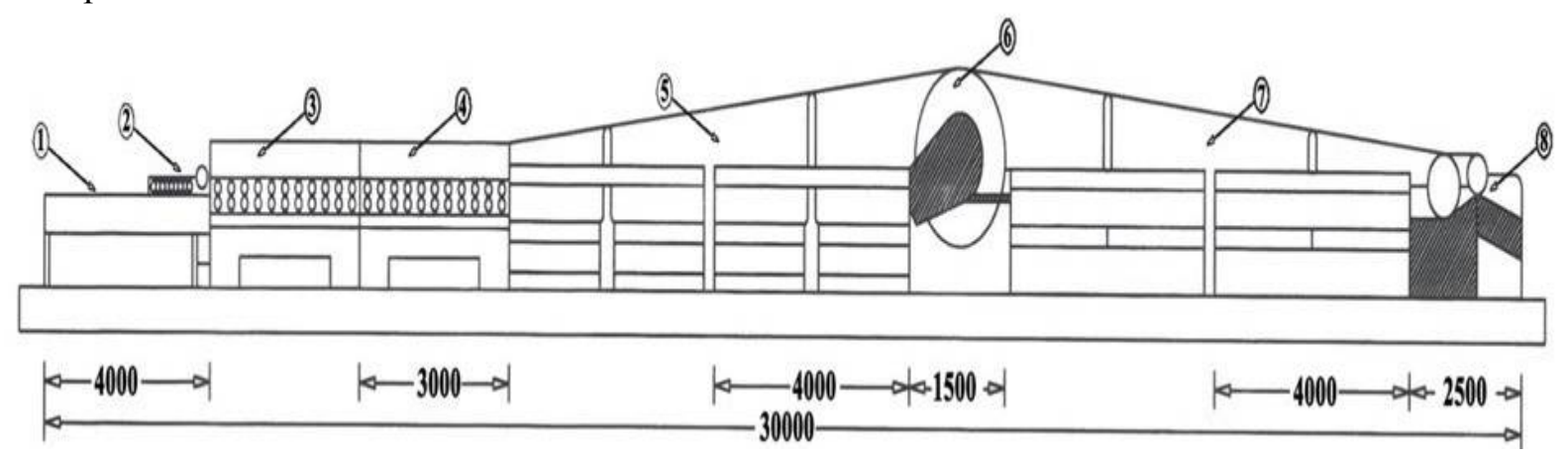

Dimensions in $\mathbf{m m}$.

\begin{tabular}{llll}
\hline No. & Part name & No. & Part name \\
\hline 1 & Inlet of straw & 2 & Working pulley \\
3 & Breaking unit for the top part of flax stems & 4 & Breaking unit for the bottom part of flax stems \\
5 & Scutching unit for the bottom part of flax stems & 6 & Transfer unit \\
9 & Scutching unit for the top part of Flax stems & 8 & Reception fiber knife \\
\hline
\end{tabular}

Fig. 4. Schematic of scutching turbine

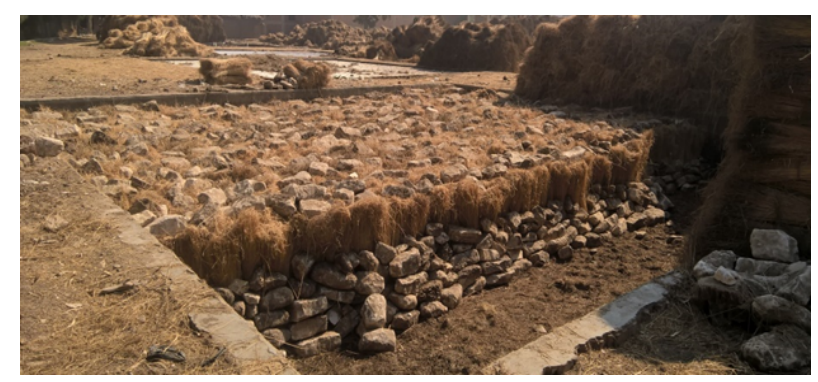

Fig. 5. Photo of retting basin 


$$
\mathrm{N}_{\mathrm{m}}=\frac{\mathrm{N} \times \mathrm{L}}{\mathrm{G}}
$$

Where:

$\mathrm{Nm}=$ Metric number, $(\mathrm{mm} / \mathrm{mg}), \mathrm{N}=$ Multiplication of Number of fibers (20 fiber, each was $10 \mathrm{~cm}$ tall), $\mathrm{L}=$ Length of fibers in $\mathrm{mm}(\mathrm{L}=\mathrm{N}$ $\times 100 \mathrm{~mm}=2000$ ), and $\mathrm{G}=$ Mass of fibers in $\mathrm{mg}$.

\section{Long fiber strength}

Long fiber strength was measured by Pressely implement (Code 231A), and determined according to Radwan and Momtaz (1966), using the following formula:

$$
\mathrm{F}_{\mathrm{s}}=\mathrm{N}_{\mathrm{m}} \times \mathrm{C}_{\mathrm{f}}=\frac{\mathrm{N} \times \mathrm{L} \times \mathrm{C}_{\mathrm{f}}}{\mathrm{G}}
$$

Where:

$\mathrm{F}_{\mathrm{S}}=$ Fiber strength, $(\mathrm{mm} \cdot \mathrm{N} / \mathrm{mg}), \mathrm{Nm}=$ Metric number, $(\mathrm{mm} / \mathrm{mg})$, and $\mathrm{C}_{\mathrm{f}}=$ Mean of the tensile force for breaking an individual fiber, $(\mathrm{N})$.

\section{System productivity (production rate)}

System productivity was calculated using the following formula:

$$
\mathrm{P}_{\mathrm{s}}=\frac{\mathrm{W}_{\mathrm{F}}}{\mathrm{t}}
$$

Where:

$\mathrm{P}_{\mathrm{s}}=$ Extraction capacity $=$ System productivity, $(\mathrm{Mg} / \mathrm{hr}), \mathrm{W}_{\mathrm{F}}=$ Total mass of Fiber, $(\mathrm{kg}), \mathrm{t}=$ the required time to extract the fiber.

\section{Fuel, power, and energy requirements}

\section{The fuel consumption rate}

The fuel volume which consumed with the time was measured by graduated cup and a stop watch respectively, then the fuel consumption rate was determined by the following equation:

$$
\text { F.c }{ }_{h}=\frac{F}{T} \times 3.6
$$

Where:

F. $\mathrm{C}_{\mathrm{h}}=$ Fuel consumption rate $(\mathrm{l} / \mathrm{hr}), \mathrm{F}=$ Volume of fuel consumption, $\left(\mathrm{cm}^{3}\right)$; and $\mathrm{T}=$ Operation time per second.

\section{The consumed power by the tractor}

The consumed power by the tractor was calculated using the measured fuel consumption during extracting operation under different variables of the study، using the following formula (Embaby, 1985)

$$
\mathrm{Ep}=\frac{\mathrm{Fc}}{3600} \times \mathrm{P}_{\mathrm{f}} \times \mathrm{LCV} \times 427 \times \eta_{\text {th }} \times \eta_{\mathrm{m}} \times \frac{1}{75} \times \frac{1}{1.36}
$$

Where:

$\mathrm{E}_{\mathrm{p}}=$ the consumed power, $(\mathrm{kW}), \mathrm{FC} .=$ Fuel consumption $(1 / \mathrm{hr}$. $), \mathrm{P}_{\mathrm{f}}=$ Fuel density $(0.85 \mathrm{~kg} / \mathrm{L}$ for diesel fuel), $\mathrm{LCV}=$ Lower calorific value of fuel $10^{4} \mathrm{kCal} / \mathrm{kg}, 427=$ Thermo-mechanical equivalent $\mathrm{kg} \cdot \mathrm{m} / \mathrm{kCal}, \eta_{\text {th }}=$ Thermal efficiency of engine, taken $40 \%, \eta_{\mathrm{m}}=$ Mechanical efficiency of engine, taken $80 \%$, and E.F.C $=$ Effective field capacity (fad. /hr).

\section{The consumed power by the electric motor}

The consumed power $(\mathrm{kW})$ was calculated from line current strength (I) and potential difference values (V) using the following formula (Ibrahim, 1982):

Total consumed power $=$ Load power $=$

$$
\frac{\sqrt{3} \mathrm{I} \times \mathrm{V} \times \eta \times \operatorname{Cos} \theta}{1000}
$$

Where:

$\mathrm{I}=$ Line current strength in Amperes., $\mathrm{V}=$ Potential difference (Voltage) being equal to 380 V., $\operatorname{Cos} \theta=$ Power factor (being equal to 0.84)., $\sqrt{3}=$ Coefficient current was three phase (equal to1.73)., $\eta=$ Mechanical efficiency (equal to $95 \%)$.

\section{Specific energy}

The specific energy consumption (kW.hr./Mg) for extracting operations was calculated as the following formula:

Specific energy $=\frac{\text { Power consumed }(\mathrm{kW})}{\text { Extracting capacity }(\mathrm{Mg} / \mathrm{hr})}$

\section{Cost Analysis}

Cost analysis was performed considering the conventional method (estimating both fixed and variable costs), (Kepner et al., 1982; Hunt, 1983) according to prices level of 2015. 


\section{RESULTS AND DISCUSSION}

In order to evaluate the extracting systems, the different criteria of extracting operation, such as quality properties of flax fibers and other factors related to extracting capacity, energy requirements and criterion cost must be taken into consideration.

\section{Fibers Separation Percentage}

From the data presented in Fig. 6, it is clear that, for all water retting methods and scutching systems, the flax fibers separation percentage decreased with the increase of the straw moisture content to certain limit.

\section{Effect of straw moisture contents, and scutching systems on flax fibers separation percentage at different retting methods}

Fig. 6 show that, changing retting water method from $\mathrm{R}_{1}$ (Retting in still water \{without changing water $\}$ ) to $\mathrm{R}_{2}$ (Retting with changing water in basin every 48 hours) tends to increase the flax fibers separation percentage. While changing water retting method from $\mathrm{R}_{2}$ (Retting with changing the water in basin every 48 hours) to $R_{3}$ (Retting with changing the water in basin every 24 hours) tends to decrease the flax fibers separation percentage.

The data shown in Fig. 6, reveale that the flax fibers separation percentage decreased by increasing of the straw moisture contents at all water retting methods and scutching systems. This is due to an increase in moisture content of flax straw increases the elasticity of straw and adhesion degree between bundled of fiber and straw wood.

For all straw moisture contents, the flax fibers separation percentage increases as the scutching systems changing from partial mechanized system to complete mechanized system. The percentage of increasing flax fibers separation percentage during extraction process with the use of partial mechanized system compared with complete mechanized system was found to be $3.11,4.67,3.81$, and $6.74 \%$ at straw moisture contents of about 8.76, 10.15, 11.90 , and $14.35 \%$ respectively under $R_{2}$ method.

The maximum values of separation percentage for partial mechanized system and complete mechanized system of (95.08, and $98.13 \%$ ) were obtained at moisture content of flax straw of $8.76 \%$, under $\mathrm{R}_{2}$ method, and scutching mill speed for partial and complete mechanized system (1075 and $1290 \mathrm{rpm})$ respectively, while the minimum values of separation percentage $(85.80$, and $92.00 \%$ ) was obtained at moisture content of flax straw of $14.35 \%$ under $\mathrm{R}_{2}$ method.

\section{Flax Fibers Length}

From the data presented in Fig. 7, it is clear that, for all water retting methods and scutching systems, the flax fibers length decreased with the increase of the straw moisture content to certain limit.

\section{Effect of straw moisture contents, and scutching systems on flax fibers length at different retting methods}

Fig. 7, show that, changing retting water method from $R_{1}$ (Retting in still water \{without changing water\}) to $\mathrm{R}_{2}$ (Retting with changing water in basin every 48 hours) tends to increase the flax fibers length. While changing water retting method from $\mathrm{R}_{2}$ (Retting with changing the water in basin every 48 hours) to $\mathrm{R}_{3}$ (Retting with changing the water in basin every 24 hours) tends to decrease the flax fibers length.

The data shown in Fig. 7, reveale that the flax fibers length decreased by increasing of the straw moisture content at all water retting methods and scutching systems. The decrease of fiber length trend is due to difficulty of fiber separation from the edges of the straws. In addition, this is due to an increase in moisture content of flax straw increases the elasticity of straw and adhesion degree between bundled of fiber and straw wood.

For all straw moisture contents, the flax fibers length increases as the scutching systems changing from partial mechanized system to complete mechanized system. The percentage of the increasing on flax fibers length during extraction process with using the partial mechanized system compared with complete mechanized system were $1.44,1.63,0.91$, and $1.57 \%$ at straw moisture content of about 8.76 , $10.15,11.90,14.35 \%$ respectively under $\mathrm{R}_{2}$ method. 

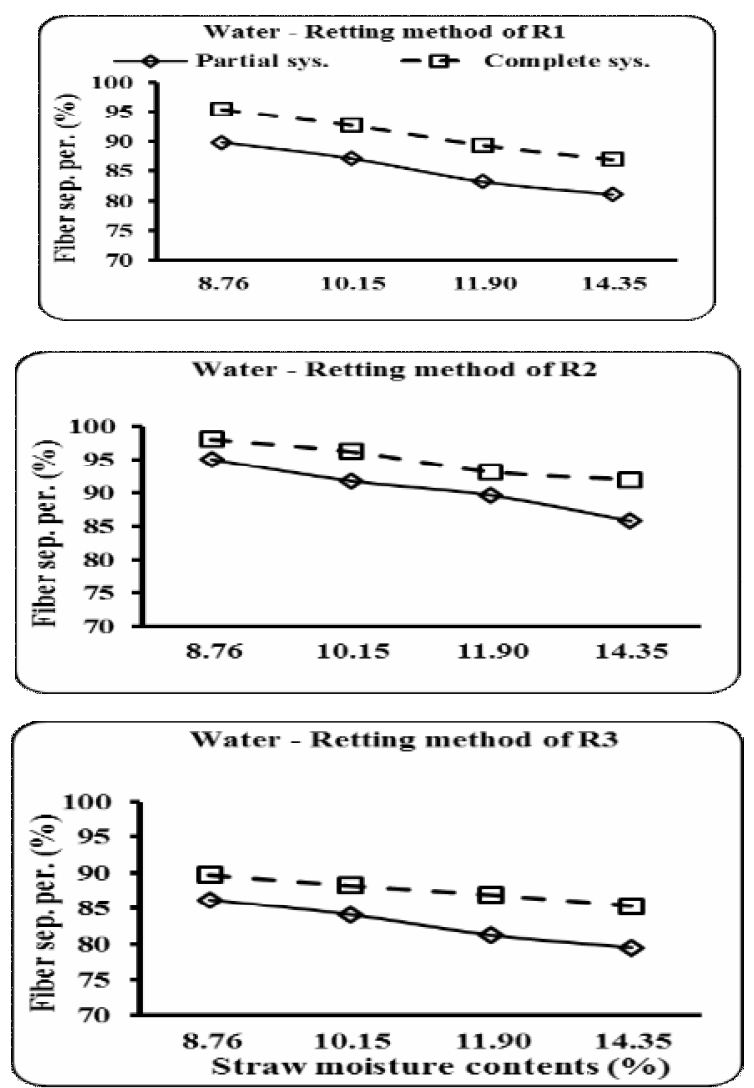

Fig. 6. Effect of straw moisture contents, and scutching systems on flax fibers separation percentage at different retting methods
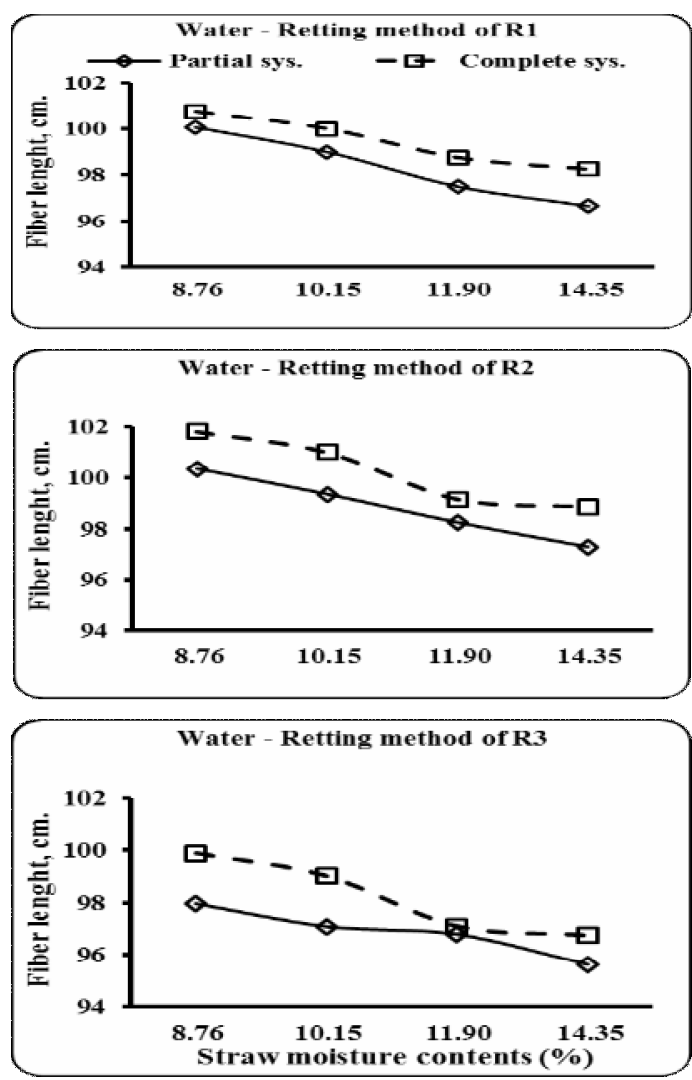

Fig. 7. Effect of straw moisture contents, and scutching systems on flax fibers length at different retting methods

Effect of straw moisture contents, and scutching systems on long flax fibers percentage at different retting methods

Figure 8 show that, changing retting water method from $R_{1}$ (Retting in still water \{without changing water\}) to $\mathrm{R}_{2}$ (Retting with changing water in basin every 48 hours) tends to increase long flax fibers percentage. While changing water retting method from $\mathrm{R}_{2}$ (Retting with changing the water in basin every 48 hours) to $\mathrm{R}_{3}$ (Retting with changing the water in basin every 24 hours) tends to decrease the long flax fibers percentage.

The data shown in Fig. 8, reveale that the long flax fibers percentage decreased by increasing the straw moisture content at all water-retting methods and scutching systems. This is due to an increase in moisture content of decreased with the increase of the straw moisture content to certain limit. 

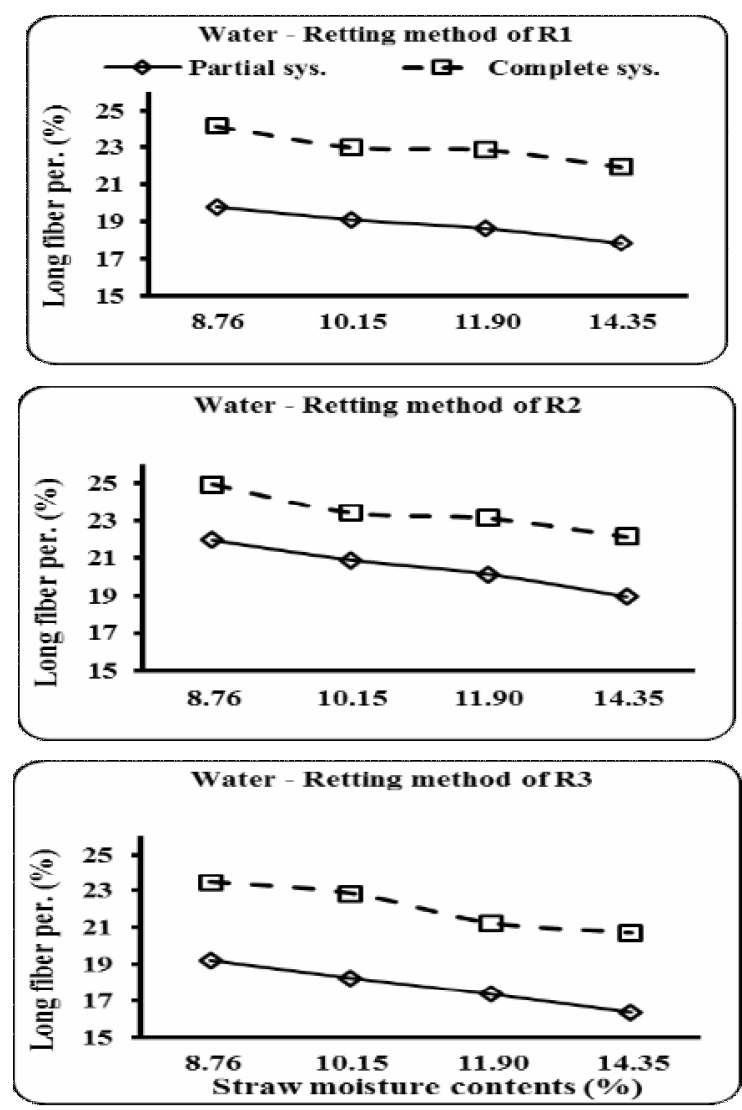

Fig. 8. Effect of straw moisture contents, and scutching systems on long flax fibers percentage at different retting methods

flax straw increases the elasticity of straw and adhesion degree between bundled of fiber and straw wood.

For all straw moisture contents, the long flax fibers percentage increases as the scutching systems changed from partial mechanized system to complete mechanized system. The percentage of increasing long flax fibers percentage during extraction process with the use of partial mechanized system compared with complete mechanized system was found to be $11.99,10.76,12.85$ and $14.41 \%$ at straw moisture content of about $8.76,10.15,11.90$, $14.35 \%$ respectively under $R_{2}$ method.

The maximum values of long flax fibers percentage for partial mechanized system and complete mechanized system of $(21.95$, and $24.94 \%$ ) were obtained at moisture content of flax straw of $8.76 \%$, under $\mathrm{R}_{2}$ method, and scutching mill speed for partial and complete mechanized system (1075 and $1290 \mathrm{rpm})$ respectively, while the minimum values of long flax fibers percentage (18.95 and 22.14\%) were obtained at moisture content of flax straw of $14.35 \%$ under $\mathrm{R}_{2}$ method.

\section{Flax Fibers Fineness}

From the data presented in Fig. 9, it is clear that, for all water retting methods and scutching systems, the flax fibers fineness decreased with the increase of the straw moisture content to certain limit.

\section{Effect of straw moisture contents, and scutching systems on flax fibers fineness at different retting methods}

Figure 9 show that, changing retting water method from $R_{1}$ (Retting in still water \{without changing water\}) to $\mathrm{R}_{2}$ (Retting with changing water in basin every 48 hours) tends to increase the flax fibers fineness. While changing water retting method from $\mathrm{R}_{2}$ (Retting with changing 


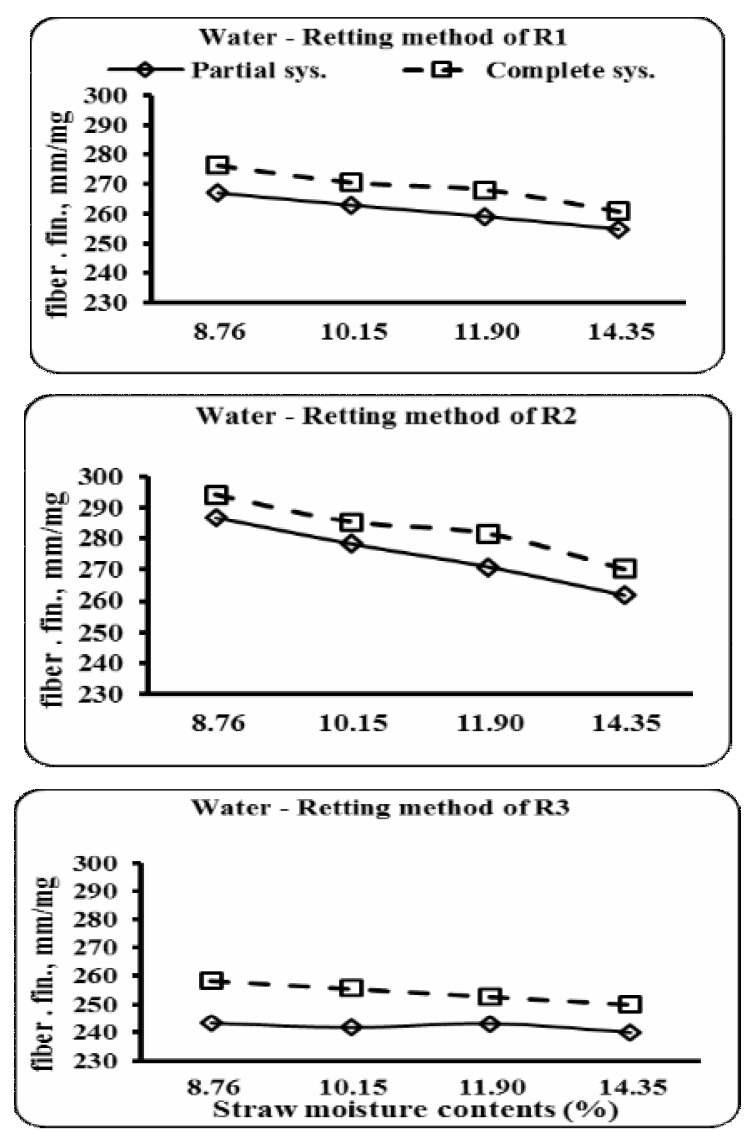

Fig. 9. Effect of straw moisture contents, and scutching systems on flax fibers fineness at different retting methods

the water in basin every 48 hours) to $\mathrm{R}_{3}$ (Retting with changing the water in basin every 24 hours) tends to decrease the flax fibers fineness.

The data shown in Fig. 9, reveale that the flax fibers fineness decreased by increasing the straw moisture content at all water-retting methods and scutching systems. This is due to an increasing straw moisture content decrease the fiber fineness because of the increase in mass of fiber.

For all straw moisture contents, the flax fibers fineness increases as the scutching systems changed from partial mechanized system to complete mechanized system. The percentage of increasing flax fibers fineness during extraction process with the use of partial mechanized system compared with complete mechanized system was found to be $2.57,2.54$, 3.80 , and $3.14 \%$ at straw moisture content of about $8.76,10.15,11.90,14.35 \%$ respectively and under $\mathrm{R}_{2}$ method.

The maximum values of flax fibers fineness for partial mechanized system and complete mechanized system of (286.70, and 294.27 $\mathrm{mm} / \mathrm{mg}$.) were obtained at moisture content of flax straw of $8.76 \%$, under $\mathrm{R}_{2}$ method, and scutching mill speed for partial and complete mechanized system (1075 and $1290 \mathrm{rpm})$ respectively, while the minimum values of flax fibers fineness $(261.80$, and $270.30 \mathrm{~mm} / \mathrm{mg}$.) were obtained at moisture content of flax straw of $14.35 \%$ and under $\mathrm{R}_{2}$ method.

\section{Flax Fibers Strength}

From the data presented in Fig. 10, it is clear that, for all water retting methods and scutching systems, the flax fibers strength increased with the increase of the straw moisture content to certain limit.

\section{Effect of straw moisture contents, and scutching systems on flax fibers strength at different retting methods}

Figure 10 show that, changing retting water method from $\mathrm{R}_{1}$ (Retting in still water \{without changing water\}) to $\mathrm{R}_{2}$ (Retting with changing 

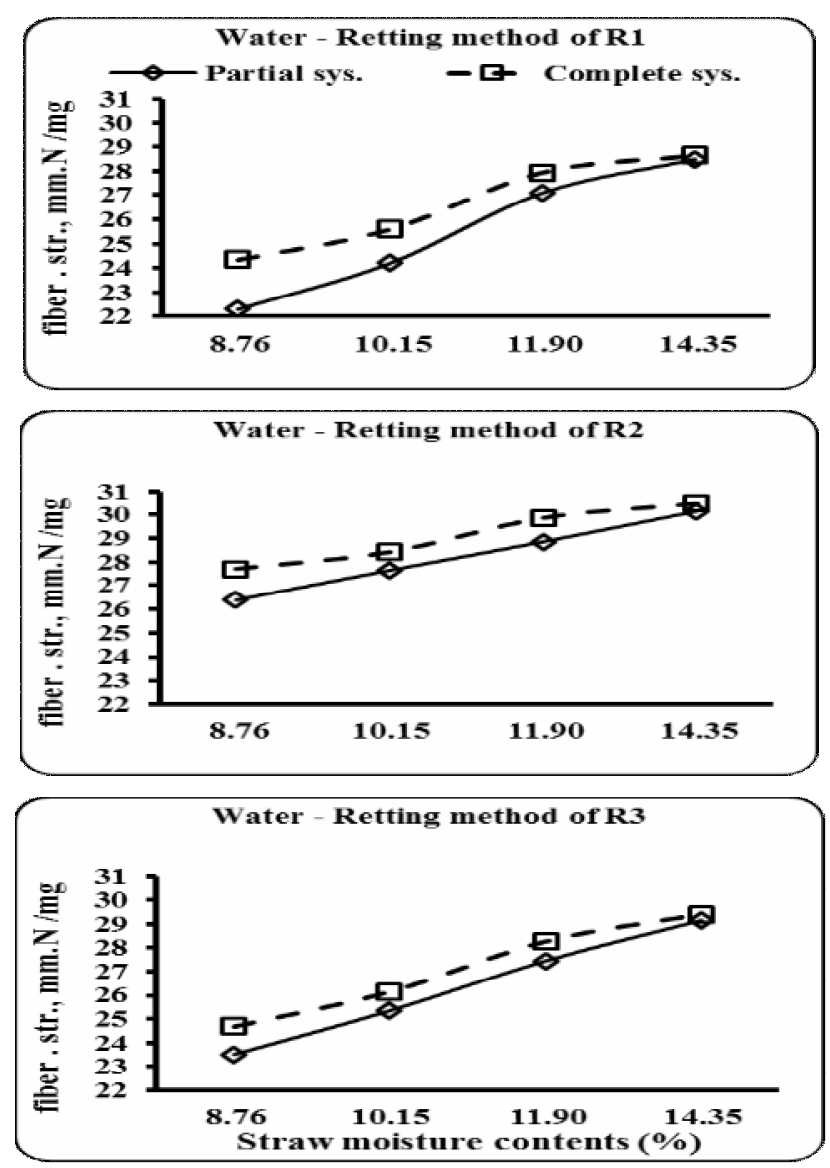

Fig. 10. Effect of straw moisture contents, and scutching systems on flax fibers strength at different retting methods

water in basin every 48 hours) tends to increase flax fibers strength. While changing water retting method from $\mathrm{R}_{2}$ (Retting with changing the water in basin every 48 hours) to $R_{3}$ (Retting with changing the water in basin every 24 hours) tends to decrease the flax fibers strength.

The data shown in Fig. 10, reveale that the flax fibers strength decreased by increasing straw moisture content at all water-retting methods and scutching systems. This is due to an increasing the fibers strength trend to increase in the elasticity degree with increasing straw moisture contents. In addition, the loss of strength was attributed to the breakdown of technical fibers into their component elementary fibers due to the deterioration of the lignin that holds the elementary fibers together.

For all straw moisture contents, the flax fibers strength increases as the scutching systems changed from partial mechanized system to complete mechanized system. The percentage of increasing flax fibers strength during extraction process with the use of partial mechanized system compared with complete mechanized system was found to be $4.73,2.71$, 3.38 , and $1.08 \%$ at straw moisture content of about $8.76,10.15,11.90,14.35 \%$ respectively and under $\mathrm{R}_{2}$ method.

The maximum values of flax fibers strength for partial mechanized system and complete mechanized system of $(30.15$, and 30.48 $\mathrm{mm} . \mathrm{N} / \mathrm{mg}$.) were obtained at moisture content of flax straw of $14.35 \%$, under $\mathrm{R}_{2}$ method, and scutching mill speed for partial and complete mechanized system (1075 and $1290 \mathrm{rpm})$ respectively, while the minimum values of flax fibers strength (26.39, and $27.70 \mathrm{~mm} . \mathrm{N} / \mathrm{mg}$.) were obtained at moisture content of flax straw of $8.76 \%$ and under $\mathrm{R}_{2}$ method.

\section{Power and Specific Energy}

Table 2, show the power and specific energy as affected by different flax fiber extracting systems and mean moisture contents of straw. 
Table 2. Power and Specific energy for partial and complete mechanized system during extraction process

\begin{tabular}{lcccccc}
\hline & \multicolumn{2}{c}{ Scutching systems } & & \multicolumn{2}{c}{ Difference } \\
\cline { 2 - 3 } \cline { 6 - 7 } & Partial & Complete & & Amount & $\mathbf{( \% )}$ \\
\hline Number of labour & 30.00 & 12.00 & & $\mathbf{1 8 . 0 0}$ & $\mathbf{6 0 . 0 0}$ \\
Human energy, $\mathbf{k W}$. & 2.24 & 0.90 & & $\mathbf{1 . 3 4}$ & $\mathbf{6 0 . 0 0}$ \\
Fuel consumption, $\mathbf{l}$. & 7.50 & 20.00 & & $\mathbf{1 2 . 5 0}$ & $\mathbf{6 2 . 5 0}$ \\
Power consumed, $\mathbf{k W}$. & 23.70 & 63.20 & & $\mathbf{3 9 . 5 0}$ & $\mathbf{6 2 . 5 0}$ \\
Total power consumed, $\mathbf{k W}$. & 25.94 & 64.10 & & $\mathbf{3 8 . 1 6}$ & $\mathbf{5 9 . 5 3}$ \\
Extraction capacity, $\mathbf{M g} / \mathbf{h r}$. & 0.54 & 1.60 & & $\mathbf{1 . 0 6}$ & $\mathbf{6 6 . 2 5}$ \\
Specific energy, $\mathbf{k W} . \mathbf{h r} . \mathbf{M g}$ & 48.03 & 40.06 & & $\mathbf{7 . 9 7}$ & $\mathbf{1 6 . 6 0}$ \\
\hline
\end{tabular}

It is remarkable that the specific energy for extracting operation decreased with the decrease of straw moisture content for any extracting system. For all water retting methods, the power requirement increased and specific energy decreased for both partial mechanized system and complete mechanized system. The mean values of total power requirement for extracting flax fiber $(\mathrm{kW})$ by using complete system is greater than the partial system by $59.53 \%$ as shown in Table 2. This trend is due to the number of labour as well as the fuel consumption in $(1 / \mathrm{hr})$ of the complete system is greater than the partial system. On the other hand, the mean values of specific energy for extracting operation (kW. hr/Mg.) for the complete system is lower than the partial system by $16.60 \%$. This trend is due to the productivity of complete system is greater than the partial system. This attributed to the low attachment strength of the low moisture content straws then for high moisture content straws that tend to decrease specific energy. This trend is due to the productivity of extracting complete system is greater than the productivity of extracting partial system.

\section{The Cost Analysis}

Table 3 shows the associated costs related to the different systems of flax fiber extracting. The first one was partial mechanized system powered by $62 \mathrm{hp}(46.26 \mathrm{~kW})$ tractor, and the second was complete mechanized system powered by $200 \mathrm{hp}(160 \mathrm{~kW})$ electric generator. The mean values of total cost for extracting flax fiber (LE/hr) by using complete system is greater than the partial system by $29.49 \%$ as shown in Table 3. This trend is due to the list price as well as the fuel consumption in $(1 / \mathrm{hr})$ of the complete system is greater than the partial system. On the other hand, the mean values of total cost per unit rate of work ( $\mathrm{LE} / \mathrm{Mg}$ ) for the complete system is lower than the partial system by $60.36 \%$. This trend is due to the productivity of complete system is greater than the partial system. Comparing the results of different systems with respect to the criterion cost in $\mathrm{LE} / \mathrm{Mg}$ point of view, one can realize that the minimum cost is associated with the complete mechanized system $(504.59 \mathrm{LE} / \mathrm{Mg})$ followed by the partial mechanized system (1272.80 $\mathrm{LE} / \mathrm{Mg}$ ) respectively. That indicates the importance of using the complete mechanized system. The previous comparison may mislead the reader in some way because the fiber losses of each system differ from each other. To overcome this difficulty the losses of each system has been considered. The fiber losses costs were reached $(240,720 \mathrm{LE} / \mathrm{Mg})$ for the complete mechanized system and the partial mechanized system, respectively. It was believed that the criterion cost would be much better and actually represents the suitability of different system. 
Table 3. Cost analysis for partial and complete mechanized flax fiber extraction system

\begin{tabular}{lcccccc}
\hline & \multicolumn{2}{c}{ Scutching systems } & & \multicolumn{2}{c}{ Difference } \\
\cline { 2 - 3 } \cline { 6 - 7 } & Partial & Complete & & Amount & $\mathbf{( \% )}$ \\
\hline Total cost, LE./hr. & 298.51 & 423.35 & & $\mathbf{1 2 4 . 8 4}$ & $\mathbf{2 9 . 4 9}$ \\
Operating cost, $\mathbf{L E}$./Mg & 552.80 & 264.59 & & $\mathbf{2 8 8 . 2 1}$ & $\mathbf{5 2 . 1 4}$ \\
Criterion costs, $\mathbf{L E} . / \mathbf{M g}$ & 1272.80 & 504.59 & & $\mathbf{7 6 8 . 2 1}$ & $\mathbf{6 0 . 3 6}$ \\
\hline
\end{tabular}

\section{Conclusion}

It can be concluded that the proper system to extract fiber flax under local conditions is complete mechanized system and retting flax straw with changing the water in basin every 48 hours. The moisture content of retted straw must be about $10.15 \%$ w.b. This system of extracting fiber flax has given the highest values of flax fibers separation percentage of $(96.30 \%)$, flax fiber length of $(101.00 \mathrm{~cm})$, long fiber percentage of $(23.42 \%)$, fiber fineness of (285.45 mm/mg), and long fiber strength of $(28.42 \mathrm{~mm} . \mathrm{N} / \mathrm{mg})$, and the lowest values of specific energy for separate one $\mathrm{Mg}$ of flax straw of $(40.06 \mathrm{~kW} . \mathrm{hr} / \mathrm{Mg})$, and criterion costs of $(504.59 \mathrm{LE} / \mathrm{Mg})$.

\section{REFERENCES}

ASAE Yearbook Standard (1992). Agricultural engineers year-book. ASAE. St. Joseph, Ml., 303 (1): 269 - 358.

Azza I. Hafez, Maaly A. Khedr, and Randa M. Osman (2012). Flax retting wastewater Part 1: Anaerobic treatment by using UASB reactor, Nat. Res. J., 7 (3): 191-200.

Bos, H.L. (2004) .The potential of flax fibres as reinforcement for composite materials. D. $\mathrm{Ph}$. Thesis, Eindhoven University of Technology, Eindhoven, the Netherlands.

Embaby, A.T. (1985). A comparison of different mechanization system for cereal crop production. M. Sc. Thesis, Fac. Agric., Agric. Eng., Cairo Univ.

FAO Statistical Year Book (2013). World food and agriculture, Food and Agriculture
Organization of the United Nations, Economic and Soc. Dev. Dept., Roma.

Hunt, D. (1983). Farm Power and Machinery Management. $8^{\text {th }}$ Ed. lowa State Univ. Press, Ames, USA., 59-76.

Ibrahim, M.K.E. (1982). Wet milling of wheat grain. M.Sc. Thesis, Fac. Agric., Mansoura Univ.

Kepner, R.A., R. Bainer and L.E. Barger (1982). Principle of Farm Machinery, The AVI Pub. Comp. INC, Westport Conn., 392- 431.

Konczewicz, W., N. Kryszak, E. Nowaczkiewicz, R. Kozlowski, J. Wojtysiak and W. Podsiedlik (2013). Osmosis phenomena based degumming of bast fibrous plants as a promising method in primary processing. Molecular Crystals and Liquid Crystals, 571(1): 116-131.

Nair, G.R., Z. Li, Y. Gariepy, G.S.V. Raghavan (2011). Microwave drying of corn (Zea mays L. ssp.) for the seed industry. Dry. Technol., 29: 1291-1296.

Radwan, B.R.H. and A. Momtaz (1966).The technological properties of flax fibers and the methods of estimating them. El-Felaha J., 46 (5): 466-476.

Singh, J. and P.C. Bargalo (2000). Development of a small capacity double stage compression screw press for oil extraction. J. Food Eng., 43: 75-82.

Tahir, P.M., A.B. Ahmed, S.O.A. SaifulAzry and Z. Ahmed (2011). Retting process of some bast plant fibres and its effect on fibre quality: A review, Bio. Res., 6 (4): 52605281. 


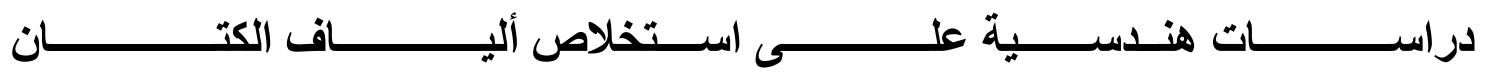

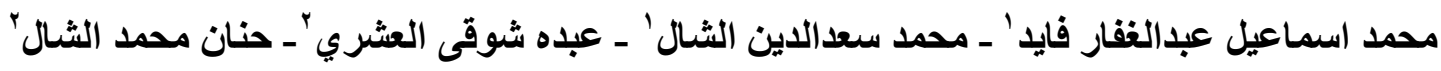

$$
\begin{aligned}
& \text { ا ـ قسم الهندسة الزر اعيةـ كلية الزر اعةــ جامعة الزقازيق }
\end{aligned}
$$

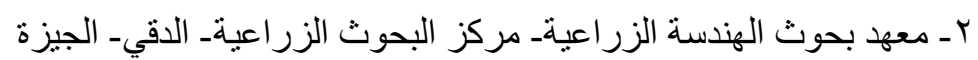

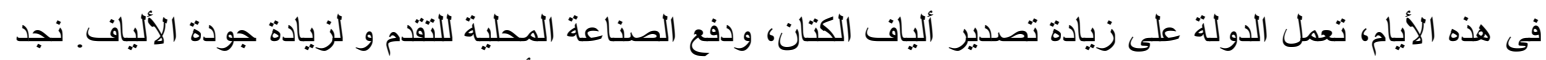

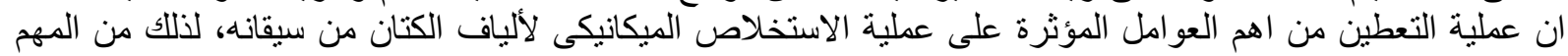

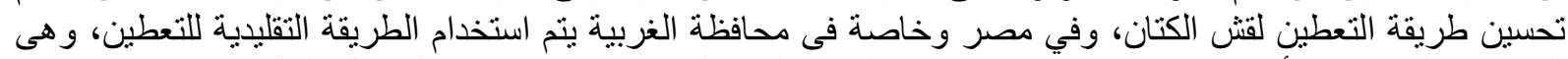

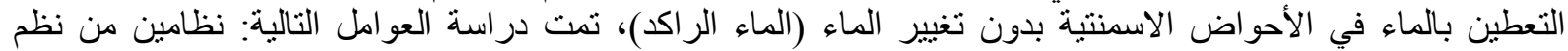

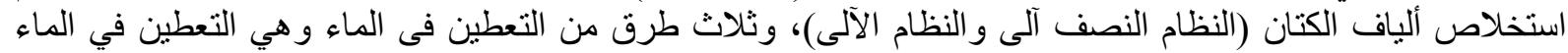

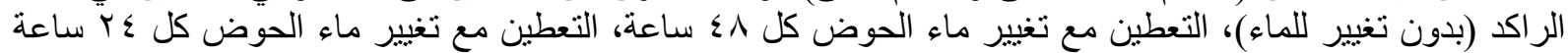

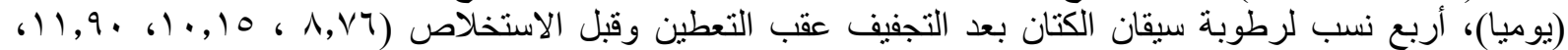

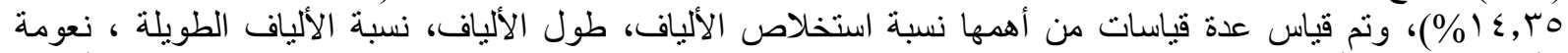

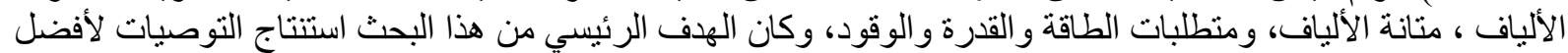

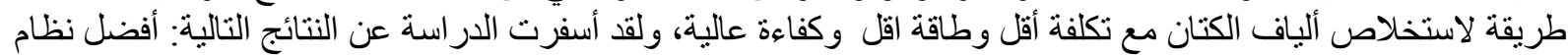

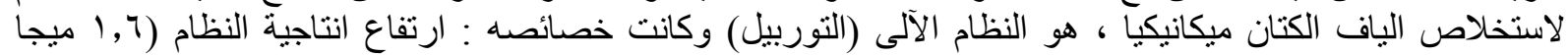

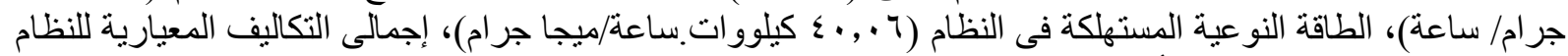

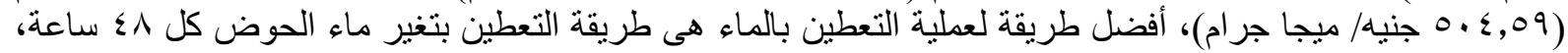

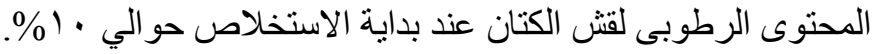

